Vol 5 No 2(2022) 195-210 P-ISSN 2620-295 E-ISSN 2747-0490

DOI: 1047467/elmal.v5i2.722

\title{
Strategi Pemasaran Produk Tabungan Emas Dalam Upaya Menarik Minat Nasabah pada Pegadaian Syariah Cabang Bogor Baru
}

\author{
Fikria Hasni ${ }^{1}$, Ikhwan Hamdani ${ }^{2}$, Suyud Arif ${ }^{3}$ \\ 1,2,3Universitas Ibnu Khaldun Bogor \\ fikriaaaa2402@gmail.com¹, onehamdani@gmail.com²,suyudarif@fai.uika-bogor.ac.id³
}

\begin{abstract}
This study aims to explain the marketing strategy in marketing the gold savings products found at Pegadaian Syariah Bogor Baru and how the right strategy is to attract customers to use the Gold Savings product. This research is a field research using a qualitative descriptive approach with primary and secondary data sources. In collecting data, researchers used interviews, observation and documentation techniques. The resource persons of this study were three employees of the Syariah Pawnshop Bogor Baru Branch and two customers of the Gold Savings product. The results of this study indicate that the application of marketing strategies provides services and information that is quite good for customers of gold savings products. From the aspect of the marketing mix contained in the branch office, such as; advertising, personal selling, sales promotion, publicity and direct marketing. Thus, the right strategy is to attract more customers by developing digital technology, this media has been loved by all generations because it can be easily accessed and at any time so that the strategy through digital will be very effective to reach as a whole.
\end{abstract}

Keywords: marketing strategy, sharia pawnshop, gold savings

\section{ABSTRAK}

Penelitian ini bertujuan untuk menjelaskan strategi pemasaran dalam memasarkan produk tabungan emas yang terdapat di Pegadaian Syariah Bogor Baru dan bagaimana strategi yang tepat agar menarik minat nasabah untuk menggunakan produk Tabungan Emas. Penelitian ini merupakan penelitian lapangan (field research) dengan menggunakan pendekatan deskriptif kualitatif dengan sumber data primer dan sekunder. Dalam pengumpulkan data, peneliti menggunakan teknik wawancara, observasi dan dokumentasi. Narasumber dari penelitian ini ada tiga orang pegawai dari Pegadaian Syariah Cabang Bogor Baru dan dua Nasabah produk Tabungan Emas. Hasil dari penelitian ini menunjukan bahwa penerapan strategi pemasaran memberikan pelayanan dan informasi yang cukup baik untuk nasabah produk tabungan emas. Dari aspek marketing mix yang terdapat di kantor cabang tersebut seperti; periklanan, penjualan pribadi, promosi penjualan, publisitas dan direct marketing. Dengan demikian, strategi yang tepat untuk menarik lebih banyak nasabah dengan mengembangkan teknologi digital, karena media tersebut sudah banyak digandrungi oleh seluruh generasi karena dapat dengan mudah diakses dimanapun dan kapanpun sehingga strategi melalui digital tersebut akan sangat efektif untuk menjangkau secara keseluruhan.

Kata Kunci : strategi pemasaran, pegadaian syariah, tabungan emas 


\section{Vol 5 No 2(2022) 195-210 P-ISSN 2620-295 E-ISSN 2747-0490 DOI: 1047467/elmal.v5i2.722}

\section{PENDAHULUAN}

Kebutuhan manusia setiap hari selalu meningkat terutama kebutuhan keuangan. Oleh karena itu, untuk bisa memenuhi kebutuhan tersebut seharusnya dapat membuat suatu rencana yang sangat efektif untuk masa depan yang baik. Islam pun mendorong manusia untuk selalu memanfaatkan hartanya. Sumber daya yang dimiliki tidak boleh hanya disimpan, tetapi harus dijadikan sebagai aset produktif agar memberikan kemanfaatan bagi sesama umat manusia. Dalam ekonomi syariah kegiatan menabung sangat diperlukan. Namun dorongan ini bukan tanpa batas, menabung dalam artian sebagai manusia tidak boleh serakah dengan hanya memikirkan kepentingan pribadi. Etika bisnis dan menabung juga harus tetap dilandasi norma, etika, dan tuntunan syariah yang bersumber dari Al-Qur'an dan Al-Sunnah. Strategi dalam pemasaran merupakan suatu cara untuk memenangkan "perang". Strategi sangat penting dan diperlukan dalam berbisnis syariah dengan ketentuan strategi tersebut tidak melanggar aturan yang syariat Islam seperti tidak melakukan kebohongan dan penipuan, tidak melakukan caracara yang batil dalam menghalalkan sesuatu yang berkaitan dengan bisnis dan tidak merugikan pihak lain. Oleh karena itu, perlu adanya Strategi pemasaran yang tepat untuk diterapkan dalam produk tabungan emas agar menarik minat nasabah di Pegadaian Syariah Cabang Bogor Baru. Strategi pemasaran merupakan kemampuan untuk menjual atau mendistribusikan produk yang ada agar apa yang menjadi target dari perusahaan dapat tercapai. Tujuannya agar pegadaian syariah mengetahui strategi yang tepat untuk menarik minat nasabah dan pegadaian syariah dapat memperoleh keunggulan yang lebih tinggi dibandingkan pesaing lainnya.

\section{LANDASAN TEORI}

\section{Strategi Pemasaran}

Istilah strategi berasal dari bahasa Yunani strategeia (stratos $=$ memimpin), yang artinya seni atau ilmu untuk menjadi seorang jenderal. Konsep ini relevan dengan situasi zaman dulu yang sering diwarnai dengan perang, yaitu jenderal diperlukan untuk memimpin suatu angkatan perang agar mendapatkan kemenangan. Selain itu arti dari strategi lainnya adalah sesuatu yang direncanakan untuk pembagian dan penggunaan kekuatan anggota militer dan material pada daerah-daerah dan untuk mencapai tujuan tertentu. (Sitorus \& Utami, 2017). Sedangkan pemasaran adalah suatu proses sosial dan manajerial dimana individuindividu dan kelompok-kelompok memperoleh apa yang mereka butuhkan dan 


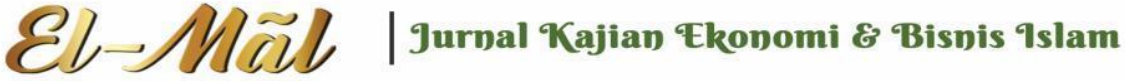

\section{Vol 5 No 2(2022) 195-210 P-ISSN 2620-295 E-ISSN 2747-0490 DOI: 1047467/elmal.v5i2.722}

inginkan dengan menciptakan dan saling mempertukarkan produk dan jasa serta nilai antara seseorang dengan yang lainnya. (Budi, 2020).

Ada lima konsep yang bersaing yang dijadikan sebagai pedoman oleh organisasi untuk melakukan kegiatan pemasaran, yaitu:

a) Konsep Produksi, menegaskan bahwa konsumen akan lebih menyukai produk yang tersedia secara luas dan murah.

b) Konsep Produk, menegaskan bahwa konsumen akan menyukai produk-produk yang menawarkan ciri paling bermutu, berkinerja, atau inovatif. Perusahaanperusahaan yang berorientasi produk sering merancang produk-produk mereka dengan sedikit atau tanpa mereka mempunyai masukan dari pelanggan.

c) Konsep Penjualan, berkeyakinan bahwa para konsumen dan perusahaan bisnis, jika dibiarkan tidak akan secara teratur membeli cukup banyak produk-produk yang ditawarkan oleh organisasi tertentu. Oleh karena itu, organisasi tersebut harus melakukan usaha penjualan dan promosi yang agresif.

d) Konsep Pemasaran, menegaskan bahwa kunci untuk mencapai tujuan organisasional yang ditetapkan adalah perusahaan tersebut harus menjadi lebih efektif dibandingkan para pesaing dalam menciptakan, menyerahkan, dan mengkomunikasikan nilai pelanggan kepada pasar sasaran yang terpadu.

e) Konsep pemasaran masyarakat, menegaskan bahwa tugas organisasi adalah menentukan kebutuhan, keinginan, dan minat dari pasar sasaran dan memberikan kepuasan yang diinginkan secara lebih efektif dan efisien dibandingkan pesaing dengan tetap memelihara atau meningkatkan kesejahteraan masyarakat dan konsumen. Konsep pemasaran masyarakat menuntut pemasar untuk memasukan pertimbangan-pertimbangan sosial dan etis ke praktek pemasaran mereka. (Ritonga dkk, 2018)

\section{Jenis Strategi Pemasaran}

Ada beberapa Jenis-jenis strategi pemasaran yang sering digunakan dan dan berlaku secara umum bagi organisasi atau perusahaan.

a. Strategi Integrasi ke depan, integrasi ke belakang, integrasi horizontal kadang semuanya disebut sebagai integrasi vertikal. Strategi integrasi vertikal memungkinkan perusahaan dapat mengendalikan para distributor, pemasok atau pesaing.

b. Strategi intensif penetrasi pasar dan pengembangan produk kadang disebut sebagai strategi intensif karena semuanya memerlukan usaha-usaha intensif jika posisi persaingan perusahaan dengan produk yang ada hendak ditingkatkan.

c. Strategi Diversifikasi terdapat tiga jenis strategi diversifikasi, yaitu diversifikasi konsentrik, horizontal, dan konglomerat. Menambah produk atau jasa baru, 


\section{Jurnal Kajian Ekonomi \& Bisnis Islam}

\section{Vol 5 No 2(2022) 195-210 P-ISSN 2620-295 E-ISSN 2747-0490 DOI: 1047467/elmal.v5i2.722}

namun masih terkait biasanya disebut diversifikasi konsentrik. Menambah produk atau jasa baru yang tidak terkait untuk pelanggan yang sudah ada disebut diversifikasi horizontal. Menambah produk atau jasa baru yang tidak disebut diversifikasi konglomerat.

d. Strategi defensif disamping strategi integrative, intensif, dan diversifikasi, organisasi juga dapat menjalankan strategi rasionalisasi biaya, divestasi, atau likuidasi. Rasionalisasi biaya, terjadi ketika suatu organisasi melakukan restrukturisasi melalui penghematan biaya dana untuk meningkatkan kembali penjualan dan laba yang sedang menurun. Kadang disebut sebagai strategi berbalik (turn around) atau reorganisasi, rasionalisasi biaya dirancang untuk memperkuat kompetensi pembeda dasar organisasi. Selama proses rasionalisasi biaya, perencana strategi bekerja dengan sumber daya terbatas dan menghadapi tekanan dari para pemegang saham,karyawan dan media. Divestasi adalah menjual suatu divisi atau bagian dari organisasi. Divestasi sering digunakan untuk meningkatkan modal yang selanjutnya akan digunakan untuk akusisi atau investasi strategis lebih lanjut. Divestasi dapat menjadi bagian dari strategi rasionalisasi biaya menyeluruh untuk melepaskan organisasi dari bisnis yang tidak menguntungkan, yang memerlukan modal terlalu besar, atau tidak cocok dengan aktivitas lainnya dalam perusahaan.

e. Strategi umum menurut Porter, ada tiga landasan strategi yang dapat membantu organisasi memperoleh keunggulan kompetitif, yaitu keunggulan biaya, diferensiasi, dan fokus. Porter menamakan ketiganya strategi umum. Keunggulan biaya menekankan pada pembuatan produk standar dengan biaya per unit sangat rendah untuk konsumen yang peka terhadap perubahan harga. (ZA, 2020).

Diferensiasi, berkaitan dengan cara membangun strategi pemasaran dalam berbagai aspek perusahaan. Kegiatan membangun strategi pemasaran inilah yang membedakan diferensiasi yang dilakukan suatu perusahaan dengan yang dilakukan oleh perusahaan lain. (Leli, 2019)

\section{Minat Nasabah}

Minat nasabah terhadap produk tabungan emas di Pegadaian Syariah dapat dikemukakan kalau minat adalah aspek yang berasal dari dalam diri manusia serta berperan sebagai pendorong dalam berbuat sesuatu yang hendak nampak pada penanda "rasa bahagia, berikan perhatian, dan berfungsi dan dalam aktivitas/ keinginan". Pengertian nasabah ialah beberapa manusia yang biasa berhubungan dalam lembaga keuangan yang bermakna sebagai pelanggan atau konsumen. Sehingga minat nasabah ialah penentuan beberapa orang kepada pemilihan antara suka atau tidak suka terhadap sesuatu objek, nilai- nilai pengalaman, perbuatan, 


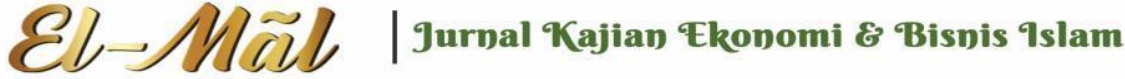

\section{Vol 5 No 2(2022) 195-210 P-ISSN 2620-295 E-ISSN 2747-0490 DOI: 1047467/elmal.v5i2.722}

kesenangan, minat, serta partisipasi seseorang terhadap sesuatu aktivitas yang disukainya.

Minat nasabah dapat diidentifikasi dengan indikator-indikator sebagai berikut:

1) Minat transaksional, ialah kecenderungan seseorang dalam membeli produk.

2) Minat referensial, ialah kecenderungan seorang dalam mereferensikan produk kepada orang lain.

3) Minat preferensial, ialah minat yang menggambarkan sikap seorang yang mempunyai preferensi utama pada produk tersebut. Preferensi ini hanya ditukar bila terdapat sesuatu dengan produk preferensinya.

4) Minat eksploratif, minat ini menggambarkan sikap seorang yang senantiasa mencari data produk yang diminatinya serta mencari informasi yang mendukung untuk menunjang sifat- sifat positif dari produk tersebut.

Minat nasabah sama maksudnya dengan perhatian, antara minat serta perhatian pada biasanya dikira sama atau tidak terdapat perbandingan. Memang keduanya nyaris sama serta dalam praktek senantiasa bergandengan satu sama lain. Bila seorang yang tertuju pada sesuatu objek sesungguhnya diawali dengan terdapatnya minat dalam hal tersebut. Minat yaitu perilaku jiwa orang seseorang tercantum fungsi ketiga jiwanya (kognisi, konasi, emosi), yang tertuju pada sesuatu serta dalam ikatan itu faktor perasaan yang terkuat. Perhatian yaitu keaktifan jiwa yang ditujukan kepada suatu objek tertentu. Di dalam indikasi perhatian, ketiga fungsi tersebut ada, namun faktor pikiranlah yang terkuat pengaruhnya. Antara minat serta perhatian senantiasa berhubungan dengan praktek. Apa yang menarik minat bisa menimbulkan adanya perhatian serta apa yang menimbulkan adanya perhatian kita terhadap sesuatu pasti diiringi dengan minat. .(Ahmadi, 2003)

\section{Pegadaian Syariah}

Definisi gadai menurut istilah syara' yaitu menahan sesuatu disebabkan adanya hak yang memungkinkan hak itu bisa dipenuhi dari sesuatu atau disebut juga perjanjian atau kesepakatan dari rahim (penggadai) ataupun murtahin (orang yang memberikan pinjaman) yang bersifat menahan sesuatu barang sebagai tanggungan utang. Kata rahn menurut bahasa berarti "tetap", "berlangsung" dan "menahan". Sedangkan menurut istilah berarti menjadikan sesuatu benda bernilai. Barang yang digadai harus harta yang memiliki nilai menurut pandangan syara' sebagai watsiqah (pengukuhan, jaminan) utang, setidaknya barang itu memungkinkan untuk digunakan membayar seluruh atau sebagian utang yang ada.

Pegadaian merupakan lembaga jaminan yang sangat terkenal dalam kehidupan masyarakat, dalam upayanya untuk mendapatkan dana untuk berbagai kebutuhan. Pegadaian Syariah merupakan salah satu unit layanan syariah yang 


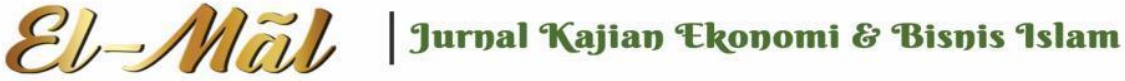

\section{Vol 5 No 2(2022) 195-210 P-ISSN 2620-295 E-ISSN 2747-0490 DOI: 1047467/elmal.v5i2.722}

dilaksanakan oleh Perusahaan Umum (PERUM) Pegadaian, di samping unit layanan konvensional. Berdirinya unit layanan syariah ini didasarkan atas perjanjian bagi hasil antara Bank Muamalat Indonesia (BMI) dengan Perum Pegadaian dengan prinsip musyarakah. Di dalam Perjanjian musyarakah Nomor 446/SP300.233/2002 dan Nomor 015/BMI/PKS/XII/2002. . (Tarantang dkk, 2019)

\section{Tabungan Emas}

Tabungan Emas merupakan layanan titipan dengan harga yang terjangkau. Layanan ini memberikan kemudahan kepada masyarakat buat berinvestasi emas. Tabungan emas ialah fasilitas investasi emas yang gampang dan dapat dilakukan oleh masyarakat umum dari berbagai macam golongan tidak terkecuali pelajar serta mahasiswa karena produk ini didapatkan dengan mudah, aman dan biaya administrasi yang terjangkau menjadi keunggulan produk ini. Produk tabungan emas ini ada pada pegadaian konvensional dengan prosedur serta ketentuan-ketentuan yang sama, tetapi terdapat perbedaan yaitu pada sistem akad dan penyimpanan uangnya saja yang berbeda sebab pada pegadaian konvensional disimpan pada bank konvensional. Sebaliknya pada Pegadaian Syariah penyimpanan uangnya semacam di Bank Syariah Mandiri atau saat ini telah menjadi Bank Syariah Indonesia. (Fitria. 2019)

Pada produk tabungan emas terdapat beberapa tahapan untuk pembukaan rekening, yaitu :

a) Pembukaan rekening melalui outlet

1) Nasabah mengisi formulir dan melampirkan fotokopi kartu identitas.

2) Nasabah membayar biaya administrasi Rp 10.000, biaya pengelolaan rekening $\mathrm{Rp} 30.000$ dan materai $\mathrm{Rp} 6.000$.

3) Nasabah membeli emas batangan dengan berat minimal 0.01 gram.

4) Nasabah mendapatkan buku tabungan emas Peraturan Direktur nomor : 173 Tahun 2019.

b) Pembukaan rekening melalui digital :

1) Download dan registrasi aplikasi Pegadaian Digital Syariah.

2) Pilih menu buka Tabungan Emas pada menu utama.

3) Input data diri dan pilih cabang lokasi pembukaan rekening.

4) Pilih metode pembayaran.

5) Lakukan pembelian emas minimal sebesar $\mathrm{Rp} 50.000$ dan lakukan pembayaran sesuai petunjuk* 


\section{Jurnal Kajian Ekonomi \& Bisnis Islam}

\section{Vol 5 No 2(2022) 195-210 P-ISSN 2620-295 E-ISSN 2747-0490 DOI: 1047467/elmal.v5i2.722}

6) Rekening telah aktif dan buku tabungan dapat diambil di cabang pendaftaran.

\section{METODE PENELITIAN}

\section{Jenis Penelitian}

Metode yang digunakan dalam penelitian ini adalah metode penelitian kualitatif, Metode penelitian kualitatif adalah metode penelitian yang digunakan untuk mendalami dan memahami pemahaman berdasarkan metodologi yang bersifat menganalisa fenomena keadaan sosial masyarakat (Sugiyono 2017). Tujuan dari penelitian deskriptifini adalah untuk membuat deskripsi, gambaran atau lukisan secara sistematis, faktual dan akurat mengenai fakta-fakta serta hubungan antar fenomena yang diteliti. Pengertian di atas dapat disimpulkan bahwa metode deskriptif adalah metode yang mencoba menggambarkan fakta atau objek dengan cara yang sistematis. (Batubara \& Nasution, 2021)

Berkaitan dengan hal ini, dimana peneliti menggambarkan fakta berupa strategi pemasaran produk tabungan emas dalam upaya menarik minat nasabah Pada Pegadaian Syariah Cabang Bogor Baru dengan sistematis sehingga tergambar dengan baik dan mudah dipahami.

\section{Jenis dan Sumber Data}

Data yang diperoleh dalam melakukan penelitian ini merupakan data yang berkaitan dengan objek penelitian, yang mana peneliti melakukan penelitian langsung kantor terkait. Sedangkan jenis data yang peneliti pakai terdapat dua jenis data yaitu data primer serta data sekunder :

1) Data primer merupakan data yang belum ada, peneliti harus memakai beberapa instrument dalam penelitian untuk mendapatkan data-data seperti kuesioner, wawancara, observasi, dan sebagainya (Tanjung \& Devi, 2018). Yang menjadi data primer dalam penelitian ini merupakan data yang diperoleh dari pihak Pegadaian Syariah Cabang Bogor Baru.

2) Data sekunder, ialah data yang sudah lebih dulu dikumpulkan serta dilaporkan oleh orang di luar peneliti sendiri, meski yang dikumpulkan itu sebetulnya merupakan data yang asli. Dengan kata lain, data sekunder merupakan data yang diperoleh dari sumber kedua, tidak hanya dari yang diteliti yang bertujuan untuk menunjang penelitian yang dilakukan (Samsu, 2017).

Data sekunder yang hendak diperoleh pada penelitian ini dari pustaka berbentuk buku-buku, majalah, internet, serta sumber lain yang dibutuhkan untuk menunjang dalam penelitian ini.

\section{Tempat Dan Waktu Penelitian}




\section{Vol 5 No 2(2022) 195-210 P-ISSN 2620-295 E-ISSN 2747-0490 DOI: 1047467/elmal.v5i2.722}

Pada penelitian ini peneliti melaksanakan penelitian di tempat yang telah dikenal oleh banyak orang yaitu, Pegadaian Syariah Kantor Cabang Bogor Baru yang beralamat di Ruko Plaza Indah Blok C No.3A, Jl. KH Sholeh Iskandar, Kel. Kedung Badak Kec. Tanah Sereal, Kota Bogor. Adapun waktu penelitian dilakukan pada bulan Juli 2021 sampai dengan selesai.

\section{Teknik \& Pengumpulan Data}

Teknik dan prosedur pengumpulan data merupakan teknik atau metode yang digunakan oleh penulis untuk mengumpulkan data yang dibutuhkannya guna mencapai tujuan penelitian. peneliti mengacu pada teknik pengumpulan data menurut Sugiyono (2013) sebagai berikut :

1) Observasi

Pengamatan observasi deskriptif dilakukan peneliti ketika memasuki situasi sosial tertentu sebagai objek penelitian. Pada tahap ini peneliti belum mengemukakan masalah yang akan diteliti, sehingga peneliti melakukan eksplorasi secara umum, dan menyeluruh, menggambarkan segala sesuatu yang dilihat, didengar, dan dirasakan. Semua data dicatat, Oleh karena itu hasil dari observasi ini disimpulkan dalam keadaan tidak teratur.

2) Wawancara

Wawancara ialah pertemuan -pertemuan orang untuk bertukar informasi serta ide dengan tanya jawab, sehingga dapat dikonstruksikan dalam suatu topik tertentu. Wawancara digunakan sebagai metode pengumpulan data bila peneliti ingin melakukan studi pendahuluan untuk menemukan masalah yang harus diteliti, tetapi juga jika peneliti ingin mengetahui hal-hal dari narasumber lebih dalam.

3) Dokumentasi

Dokumentasi ialah suatu metode pengumpulan informasi dengan cara mengambil ataupun membuat dokumen ataupun catatan yang dianggap penting. Dokumen ialah catatan kejadian yang telah berlalu. Dokumen dapat berupa tulisan, gambar, ataupun karya-karya monumental dari seorang. Dokumen yang berupa tulisan misalnya catatan harian, sejarah kehidupan (life histories), cerita, biografi, peraturan, kebijakan. Studi dokumentasi ialah pelengkap dari penggunaan metode observasi serta wawancara dalam penelitian kualitatif.

\section{HASIL DAN PEMBAHASAN}

\section{Gambaran Umum Pegadaian Syariah}




\section{Vol 5 No 2(2022) 195-210 P-ISSN 2620-295 E-ISSN 2747-0490 DOI: 1047467/elmal.v5i2.722}

Pegadaian Syariah membuka cabang yang bernama Bogor Baru, karena terletak di Kota Bogor dan berada di Jalan Baru. Nama tersebut bertujuan untuk membedakan dengan cabang Pegadaian Konvensional yang terletak di Jl. Ir Haji Juanda yang juga bernama cabang Bogor.

Pengembangan kantor cabang lainnya bertujuan untuk menjangkau masyarakat di Kota Bogor, maka secara bertahap dimulai pada tahun 2009, Pegadaian Syariah cabang Bogor mendirikan unit yang lain diantaranya; Unit Pegadaian Syariah Semplak, Bojong Gede, Bantar Kemang, Bubulak, Pahlawan, Sukahati, dan Bukit Cimanggu. Kemudian saat ini terdapat tambahan unit yang berada di Cibinong Mansion dan Graha Pos. Total Cabang Syariah Bogor Baru memiliki 9 kantor unit syariah yang tersebar di kotamadya dan kabupaten Bogor.

Pegadaian Syariah memiliki beragam produk dan jasa yang mampu memenuhi kebutuhan nasabah mulai dari individu, usaha kecil, hingga institusi berdasarkan prinsip syariah. Produk-produk yang terdapat di Pegadaian Syariah adalah:

a) Produk Rahn

b) Produk Arrum

c) Amanah

d) Tabungan Emas

Tabungan Emas Pegadaian adalah layanan penitipan emas yang memungkinkan nasabah melakukan investasi emas secara mudah, aman, dan terpercaya. Produk Tabungan Emas juga terdapat beberapa keunggulan diantaranya:

1) Jaminan emas 24 karat.

2) Biaya pengelolaan rekening ringan.

3) Pembelian mulai dari 0,01 gr.

4) Dapat dicetak fisik.

5) Dapat ditransfer ke sesama pemilik Tabungan Emas.

6) Mudah dicairkan (buyback dan gadai).

7) Dapat dilakukan secara online melalui Aplikasi Pegadaian Syariah Digital.

Pegadaian meluncurkan produk tabungan emas ini pada tahun 2015, yang bertujuan untuk meningkatkan daya tarik masyarakat terhadap investasi emas sehingga masyarakat dapat melakukan investasi emas secara praktis, mudah, dan cepat. Dengan demikian melalui surat Otoritas Jasa Keuangan Nomor S427/NB.11/2016 tanggal 17 Februari 2016, produk tersebut sudah resmi mendapat izin untuk ditawarkan kepada masyarakat. Pada bulan Agustus 2018, PT. Pegadaian (Persero) mendirikan Galeri 24 sebagai anak perusahaan yang bergerak dalam kegiatan perdagangan emas yang bertujuan untuk men-support produk emas yang berada di PT. Pegadaian (Persero). (Wawancara dengan Bapak Edy Supriyono, Divisi Penjualan, 2021) 


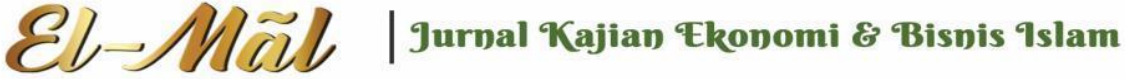

\section{Vol 5 No 2(2022) 195-210 P-ISSN 2620-295 E-ISSN 2747-0490 DOI: 1047467/elmal.v5i2.722}

Tabungan emas adalah layanan pembelian dan penjualan emas yang menggunakan fasilitas titipan dengan harga yang terjangkau, murah dan aman. Tabungan ini menggunakan akad murabahah, wadi'ah dan istishna.

Tabel 1 Daftar Biaya Cetak Emas

Sumber : Aplikasi Pegadaian Syariah Digital

\begin{tabular}{|l|l|l|l|}
\hline \multirow{2}{*}{ Denominasi } & \multicolumn{3}{|c|}{ Biaya Cetak } \\
\cline { 2 - 4 } & \multicolumn{1}{|c|}{ PT. ANTAM } & \multicolumn{1}{|c|}{ PT. UBS } & \multicolumn{1}{|c|}{ PT. Galeri 24 } \\
\hline 1 Gram & Rp. 100.000,- & Rp. 60.000,- & Rp. 50.000,- \\
\hline 2 Gram & Rp. 120.000,- & Rp. 100.000,- & Rp. 80.000,- \\
\hline 5 Gram & Rp. 200.000,- & Rp. 130.000,- & Rp. 120.000,- \\
\hline 10 Gram & Rp. 300.000,- & Rp. 200.000,- & Rp. 150.000,- \\
\hline 25 Gram & Rp. 400.000,- & Rp. 300.000,- & - \\
\hline 50 Gram & Rp. 780.000,- & Rp. 500.000,- & - \\
\hline 100 Gram & Rp. 950.000,- & Rp. 770.000,- & - \\
\hline
\end{tabular}

Tabel 2 Daftar Biaya Transaksi Tabungan Emas

Sumber : Website Pegadaian Syariah

\begin{tabular}{|l|l|l|}
\hline \multicolumn{1}{|c|}{ Transaksi } & \multicolumn{1}{|c|}{ Biaya (Rupiah) } & \multicolumn{1}{c|}{ Keterangan } \\
\hline $\begin{array}{l}\text { Transfer emas ke rekening } \\
\text { lain }\end{array}$ & Rp. 2.000,-/Transaksi & $\begin{array}{l}\text { Melalui Outlet } \\
\text { Pegadaian Syariah }\end{array}$ \\
\hline $\begin{array}{l}\text { Transfer emas ke rekening } \\
\text { lain }\end{array}$ & Rp. 0,- & $\begin{array}{l}\text { Melalui Aplikasi } \\
\text { Pegadaian Syariah }\end{array}$ \\
\hline $\begin{array}{l}\text { Pencetakan rekening koran } \\
\text { tabungan emas }\end{array}$ & Rp. 2.000,-/Lembar & $\begin{array}{l}\text { Di Outlet Pegadaian } \\
\text { Syariah }\end{array}$ \\
\hline $\begin{array}{l}\text { penggantian buku } \\
\text { Tabungan Emas yang } \\
\text { hilang atau rusak }\end{array}$ & Rp. 10.000,-/buku & $\begin{array}{l}\text { Di Outlet Pegadaian } \\
\text { Syariah }\end{array}$ \\
\hline $\begin{array}{l}\text { Penitipan emas per-tahun } \\
\text { dibayar dimuka }\end{array}$ & Rp. 30.000,-/rekening & $\begin{array}{l}\text { Di Outlet Pegadaian } \\
\text { Syariah }\end{array}$ \\
\hline penutupan rekening & Rp.30.000,-/rekening & $\begin{array}{l}\text { Di Outlet Pegadaian } \\
\text { Syariah }\end{array}$ \\
\hline
\end{tabular}

Tabel 3 Daftar Pembatasan Transaksi Tabungan Emas

Sumber : Website Pegadaian Syariah

\begin{tabular}{|l|l|l|l|}
\hline \multirow{2}{*}{\multicolumn{1}{|c}{ Transaksi }} & \multicolumn{3}{c|}{ Pembatasan } \\
\cline { 2 - 4 } & \multicolumn{1}{c|}{ Minimal } & \multicolumn{1}{c|}{ Maksimal } & Keterangan \\
\hline Pemilik rekening dapat membeli & $0.01 \mathrm{Gram}$ & $100 \mathrm{Gram}$ & Per CIF \\
\hline Pemilik rekening dapat menjual & $1 \mathrm{Gram}$ & $100 \mathrm{Gram}$ & Per CIF \\
\hline Pemilik rekening dapat mencetak & $1 \mathrm{Gram}$ & $100 \mathrm{Gram}$ & Per CIF \\
\hline $\begin{array}{l}\text { Pemilik rekening dapat } \\
\text { mentransfer }\end{array}$ & $0.01 \mathrm{Gram}$ & $100 \mathrm{Gram}$ & Per CIF \\
\hline Saldo Rekening & $0.01 \mathrm{Gram}$ & - & $\begin{array}{l}\text { Per } \\
\text { Rekening }\end{array}$ \\
\hline
\end{tabular}




\section{Iurnal Kajian Ekonomi \& Bisnis Islam}

\section{Vol 5 No 2(2022) 195-210 P-ISSN 2620-295 E-ISSN 2747-0490 DOI: 1047467/elmal.v5i2.722}

\section{Strategi Pemasaran Produk Tabungan Emas Pada Pegadaian Syariah Cabang Bogor Baru}

Pegadaian Syariah cabang Bogor Baru adalah lembaga keuangan non-bank dengan berbasis syariah. Berdasarkan hasil wawancara dengan pegawai Pegadaian Syariah Cabang Bogor Baru terkait strategi pemasaran yang dipakai terkait dengan komponen strategi pemasaran yang digunakan. Salah satunya terdapat karakteristik produk tabungan emas, yaitu;

a) Mudah yang dimaksud adalah produk tabungan emas ini mudah ditemukan di kantor cabang Pegadaian Syariah yang tersebar di wilayah Bogor Baru.

b) Murah yang dimaksud adalah harga produk tabungan emas ini sangat terjangkau. Tarif biaya administrasi setiap transaksi pembukaan rekening tabungan emas yaitu Rp 10.000,- dan biaya fasilitas titipan selama 12 bulan yaitu Rp 30.000,- sedangkan nominal pertama tidak ditetapkan akan tetapi nasabah emas batangan dengan berat minimal 0,01 gram dan nasabah sudah mendapatkan buku tabungan emas.

c) Aman yang dimaksud adalah produk tabungan emas ini sudah terdaftar dan diawasi oleh Otoritas Jasa Keuangan (OJK), transparan dalam pengelolaan, dan dikelola oleh BUMN yang sudah berpengalaman. (Wawancara dengan Ibu Yuly Arsianti, Pimpinan Cabang, 2021)

Strategi yang diterapkan di Pegadaian Syariah Cabang Bogor Baru adalah sebagai berikut :

\section{1) Advertising (Periklanan)}

Promosi melalui media iklan merupakan usaha yang dilakukan pasar untuk mempengaruhi pihak lain agar berpartisipasi dalam kegiatan pertukaran melalui iklan. Dalam memperkenalkan produk-produk yang ada termasuk produk tabungan emas, Pegadaian Syariah cabang Bogor Baru menggunakan beberapa upaya beriklan sebagai cara untuk menarik minat masyarakat. Alat promosi yang digunakan adalah media cetak dan media elektronik.

\section{2) Sales Promotion (Promosi Penjualan)}

Promosi penjualan dilakukan untuk menarik nasabah agar segera membeli produk yang ditawarkan yaitu dengan cara sosialisasi. Sosialisasi adalah suatu usaha untuk mendekatkan diri kepada masyarakat, sehingga antara satu pihak dengan pihak lainnya saling membutuhkan. Dan akan terjalin sebuah komunikasi yang baik dan akhirnya terciptanya keputusan yang baik juga. Promosi penjualan dilakukan oleh perusahaan dengan tujuan seperti menarik minat pelanggan baru, mempengaruhi pelanggan lama Pegadaian Syariah untuk mencoba produk tabungan emas.

Pegadaian Syariah Cabang Bogor Baru melakukan promosi melalui kegiatan promosi penjualan dengan cara memberikan promo-promo menarik di setiap 


\section{Vol 5 No 2(2022) 195-210 P-ISSN 2620-295 E-ISSN 2747-0490 DOI: 1047467/elmal.v5i2.722}

bulannya dengan adanya strategi tersebut masyarakat menjadi lebih mudah dan mengenal banyaknya fasilitas kelebihan-kelebihan yang ditawarkan oleh Pegadaian Syariah Cabang Bogor Baru kepada nasabah.

\section{3) Publisitas (Publicity)}

Promosi menggunakan publicity yang sering dilakukan Pegadaian Syariah melalui publisitas dapat berupa seminar, pertemuan dengan beberapa instansi, laporan tahunan, dan lain sebagainya. Kegiatan publisitas yang dilakukan Pegadaian Syariah cabang Bogor Baru adalah dengan cara mengundang masyarakat, baik nasabah dari golongan masyarakat, karyawan atau mahasiswa atau dengan mengundang pembicara yang dilakukan pada kegiatan literasi di instansi atau universitas dengan tujuan dapat menambah wawasan bagi calon nasabah untuk mengenal dan mengetahui produk yang ditawarkan.

\section{4) Penjualan Pribadi (Personal Selling)}

Penjualan perseorangan (personal selling) merupakan bentuk komunikasi antar individu dimana tenaga penjual atau wiraniaga menginformasikan, mendidik, dan melakukan persuasi kepada calon pembeli untuk membeli produk atau jasa perusahaan. Program personal selling dilakukan langsung oleh pihak manajemen Pegadaian Syariah dengan menempatkan tenaga pemasar langsung (sales executive) di lokasi sekitarnya. Para tenaga pemasar langsung (sales head) tersebut dituntut untuk mampu berkomunikasi dengan baik kepada calon konsumen. Tujuan dari kegiatan personal selling ini adalah untuk menyampaikan informasi tentang produk tabungan emas dan membujuk para nasabah sehingga calon nasabah menjadi paham dan tertarik untuk menggunakan produk tabungan emas di Pegadaian Syariah Cabang Bogor Baru. (Wawancara dengan Ibu Yuly Arsianti, Pimpinan Cabang, 2021)

Terdapat tiga cara yang dilakukan dalam personal selling yaitu:

a) Office to Office, merupakan tatap muka langsung dari perusahaan kepada calon nasabah atau karyawan perusahaan yang dilakukan dari kantor ke kantor. Adapun perusahaan yang dijadikan target adalah perusahaan swasta dan instansi pemerintahan yang sudah bekerjasama dengan Pegadaian Syariah yang bertujuan menarik pegawainya

b) Student to Student adalah bertatap muka langsung untuk mengkomunikasikan produk tabungan emas kepada calon nasabah kemudian membelinya. Adapun yang terjadi pada student to student adalah adanya hubungan yang hidup, langsung dan interaktif antara dua orang atau lebih, bahkan dalam kelompok oleh tim promosi dengan mahasiswa di Universitas yang menjadi target jualnya.

\section{5) Direct Marketing (Pemasaran dan Penjualan Langsung)}

Direct marketing adalah sistem pemasaran yang digunakan oleh Pegadaian Syariah yanbersifat interaktif, dengan memanfaatkan dua media 


\section{Jurnal Kajian Ekonomi \& Bisnis Islam}

\section{Vol 5 No 2(2022) 195-210 P-ISSN 2620-295 E-ISSN 2747-0490 DOI: 1047467/elmal.v5i2.722}

sehingga dari media iklan yang dilakukan dapat menimbulkan respon yang terukur dan melakukan transaksi dimanapun adapun media yang dimanfaatkan pemasaran langsung Pegadaian Syariah untuk produk tabungan emas sebagai berikut:

\section{a) Telemarketing}

Optimalisasi pemasaran langsung untuk mendapatkan target nasabah Pegadaian Syariah menggunakan telemarketing dilakukan untuk menawarkan berbagai fitur dan promo yang dimiliki produk tabungan emas. Pendukung pelaksanaan telemarketing di Pegadaian Syariah cabang Bogor Baru adalah dengan adanya layanan jasa Pegadaian Call Center untuk produk tabungan emas merupakan layanan tersistem kerjasama antara Pegadaian Syariah.

b) Corporate Website

Pendukung kegiatan pemasaran langsung Pegadaian Syariah terhadap pemanfaatan media internet adalah dengan membuat situs perusahaannya sendiri yaitu www.pegadaiansyariah.co.id. Keberadaan situs pribadi (corporate website) ini terhadap produk yang tersedia adalah sistem untuk menginformasikan detail dan hal-hal yang terkait khususnya dengan produk tabungan emas, dengan adanya corporate website ini di tengah zaman yang serba digital adalah hal yang menjadi penting untuk kemudahan masyarakat nasabah atau calon nasabah dalam mengakses informasi mengenai produk tabungan emas yang akhirnya timbul keinginan untuk mengetahui bahkan sampai menggunakan layanan produk tabungan emas. (Wawancara dengan Rifa Afifah, Relation Officer, 2021).

c) Events

Event yang terdapat di Pegadaian Syariah cabang Bogor Baru mempunyai fokus utama untuk menangkap perhatian dan melibatkan nasabah dalam event tersebut. Salah satu Event yang dijalankan pada tahun 2021, bernama Program GANTENG yang berlaku mulai tanggal 1 Juli s.d 30 September. Event tersebut khusus untuk Produk Gadai Tabungan Emas di seluruh kantor cabang Pegadaian Syariah dan Pegadaian Syariah Digital.

\section{Perkembangan Minat Nasabah Produk Tabungan Emas Pada Pegadaian Syariah Cabang Bogor Baru}

Berdasarkan hasil penelitian maka Pegadaian Syariah sebagai salah satu lembaga keuangan non-bank yang berbasis syariah yang unggul dan modern bukan hanya dilihat dari segi produk pembiayaan, aneka emas dan jasa. Melainkan salah satu produk unggulan Pegadaian Syariah adalah tabungan emas. Tabungan ini sejak awal kemunculannya mengalami peningkatan yang cukup baik. Tabungan emas ini membidik semua jenis kalangan masyarakat. Mengingat tidak adanya data khusus 


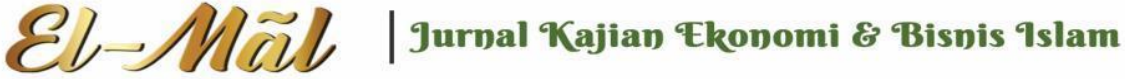

\section{Vol 5 No 2(2022) 195-210 P-ISSN 2620-295 E-ISSN 2747-0490 DOI: 1047467/elmal.v5i2.722}

yang diperoleh peneliti karena terdapat kerahasiaan nasabah Pegadaian Syariah maka peneliti hanya mendapatkan data jumlah nasabah per tahun saja.

Tabel 4 Perkembangan Jumlah Nasabah Pegadaian Syariah Cabang Bogor Baru

Sumber : Dokumen Pegadaian Syariah, 2021

\begin{tabular}{|c|c|c|}
\hline No. & Tahun & Jumlah Nasabah \\
\hline & 2020 & 1.155 \\
\hline & Januari - September 2021 & 1.606 \\
\hline
\end{tabular}

Dengan adanya strategi pemasaran yang telah dijabarkan diatas, setiap tahunnya produk tabungan emas mengalami peningkatan sejak awal tahun 2020 jumlah nasabah 1.155 sampai saat ini jumlah nasabah menjadi 1.606 per-bulan September 2021. Setiap tahunnya mengalami peningkatan karena semakin sadarnya masyarakat akan keuntungan menabung emas maka tidak sedikit masyarakat yang sudah memiliki tabungan emas. Peningkatan jumlah nasabah tabungan emas tersebut tidak luput dari kerja keras semua pegawai Pegadaian Syariah cabang Bogor Baru.

\section{KESIMPULAN DAN SARAN}

Berdasarkan hasil penelitian yang dilakukan, maka dapat diambil kesimpulan bahwa strategi pemasaran produk tabungan emas dalam upaya menarik minat nasabah pada Pegadaian Syariah cabang Bogor Baru adalah sebagai berikut:

1. Strategi pemasaran produk tabungan emas yang digunakan oleh Pegadaian Syariah Cabang Bogor Baru menggunakan strategi promosi pemasaran, yaitu :

a) Advertising (Periklanan) diantaranya dengan menyebarkan brosur kepada masyarakat, memasang spanduk, banner dan lainnya oleh Pegadaian Syariah Cabang Bogor Baru.

b) Sales Promotion (Promosi Penjualan) diantaranya dengan melakukan promosi melalui kegiatan promosi penjualan dengan cara memberikan promo-promo menarik di setiap bulannya.

c) Publicity (Publisitas) diantaranya dengan mengundang masyarakat, baik nasabah dari golongan masyarakat, karyawan atau mahasiswa atau dengan mengundang pembicara yang dilakukan pada kegiatan literasi di instansi atau universitas.

d) Penjualan Pribadi (Personal Selling) diantaranya dengan menempatkan tenaga pemasar langsung (sales executive) di lokasi sekitarnya. Di kantor Cabang Bogor Baru tidak hanya bagian marketing saja yang harus mempromosikan produk, 


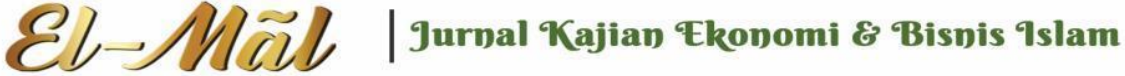

\section{Vol 5 No 2(2022) 195-210 P-ISSN 2620-295 E-ISSN 2747-0490 DOI: 1047467/elmal.v5i2.722}

tetapi seluruh karyawan mulai dari satpam, kasir, relation officer sampai ke pimpinan cabang juga berkewajiban melakukan promosi tersebut.

e) Direct Marketing (Pemasaran dan Penjualan Langsung) diantaranya dengan adanya layanan jasa Pegadaian Call Center, dengan memasang iklan di radio, televisi, penggunaan media elektronik (melalui website dan sosial media).

2. Strategi pemasaran yang lebih tepat dalam menarik minat nasabah yaitu menggunakan metode teknologi digital. Teknologi digital yang dimaksud dengan menggunakan sosial media dan situs website yang bertujuan sebagai media pemasaran ataupun promosi dapat dengan mudah untuk menjangkau semua kalangan masyarakat dimanapun berada, sehingga menarik minat masyarakat untuk membuka dan memilih produk tabungan emas. Selain hal tersebut media sosial juga dapat digunakann untuk memberikan informasi mengenai produk, events, webinar, ataupun hal lainnya. Dengan menggunakan sosial media maka akan lebih mudah dalam memberikan informasi mengenai produk tabungan emas.

Setelah penelitian data didapatkan beberapa fakta, maka peneliti memiliki beberapa saran yaitu :

1) Bagi Pegadaian Syariah cabang Bogor Baru

Pegadaian Syariah Cabang Bogor Baru harus lebih giat dalam melakukan promosi pada produk tabungan emas dan produk lainnya. Pegadaian Syariah secara keseluruhan harus senantiasa mengembangkan kualitas produk dan kualitas pelayanan penjualan yang baik terhadap nasabah, selain itu Pegadaian Syariah harus tetap mempertahankan dengan terus meningkatkan layanan tabungan emas dan memperhatikan produk lainnya. Program-program pengembangan kepada masyarakat yang semakin hari semakin meningkatkan agar lebih banyak nasabah yang tertarik menggunakan produk tabungan emas.

2) Bagi Nasabah

Sebagai mayoritas penduduk Indonesia adalah umat Islam. Oleh karena itu, sudah banyak lembaga keuangan non-bank yang syariah. Dengan demikian masyarakat saat ini seharusnya menggunakan setiap produk yang menggunakan sistem syariah dan telah dikembangkan saat ini oleh Pegadaian Syariah yaitu produk tabungan emas.

3) Bagi Peneliti Lain

Bagi peneliti selanjutnya, diharapkan dapat mengkaji lebih dalam bagaimana Pegadaian Syariah cabang Bogor Baru dalam melakukan strategi pemasaran yang sesuai dengan syariat Islam. Selain itu hendaknya menambah variabelvariabel dalam penelitiannya, tidak hanya produk tabungan emas tetapi ditambah dengan produk yang lain. 


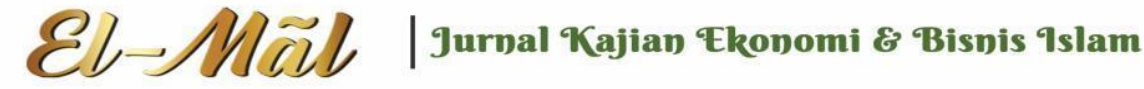

\section{Vol 5 No 2(2022) 195-210 P-ISSN 2620-295 E-ISSN 2747-0490 DOI: $1047467 /$ elmal.v5i2.722}

\section{DAFTAR PUSTAKA}

Ascarya, P. (2011). Akad dan Produk Bank Syariah. Jakarta: PT. Grafindo Persada.

Budi, M. S. (2020). STRATEGI PEMASARAN PRODUK TABUNGAN EMAS DALAM MENARIK MINAT NASABAH DI PEGADAIAN SYARIAH UNIT BURNEH $B A N G K A L A N$ (Doctoral dissertation, Sekolah Tinggi Agama Islam Darul Hikmah Bangkalan).

Fitria, R. (2019). Strategi Pemasaran Tabungan Emas Pada PT Pegadaian (Persero) Unit Syariah Simpang Benteng Payakumbuh.

Kanwil VIII Jakarta. (2020). Booklet Produk Pegadaian. Jakarta: Pegadaian.

Putri Dr. Budi Rahayu Tanama, S.Pt., MM. (2017). Manajemen Pemasaran. Denpasar: Fakultas Peternakan Universitas Udayana.

Ritonga, BA, M.Sc M. Husni Muharram , Fikri, S.E., M.Si, Siregar, S.E., M.Si, (2017). Manajemen Pemasaran dan Konsep Strategi, Medan.

Sitorus, O. F., \& Utami, N. (2017). Strategi Promosi Pemasaran. Jakarta: FKIP UHAMKA

Sugiyono. (2016). Metode Penelitian Kuantitatif, Kualitatif, dan R\&D. Bandung: Alfabeta. Hal 245-277.

Tanjung, Hendri., \& Devi, Abrista. (2018). Metodologi Penelitian Ekonomi Islam. Bekasi: Gratama.

Tarantang, J., Astuti, M., Awwaliyah, A., \& Munawaroh, M. (2019). Regulasi dan implementasi pegadaian syariah di Indonesia.

ZA, S. Z. (2020). MANAJEMEN PEMASARAN Teori dan Strategi. NTB: Forum Pemuda Aswaja. 